carboxylase, phosphocenolpyruvate carboxylase and fructose-1 6-diphosphattase in muscles from vertebrates and invertebrates. Biochem. J., 1.30):391 (1972).

4. Cremer, J. F., and Teal, H. M.: Develepment of pyruvate dehydrogenase in rat hrain. FHBS L.ctt.. 39: $17(1974)$

11). Farmer. T. W.. Veath. I... Miller. A. I.. OBBrien. J. S., and Renenberg. R M.: Pyruvate decartoxylase deficiency in a pattent with subatcute necrotising encephalomvelopathy Neurology. 2.3: $224(197.3)$

11. Farrel, D. F.. Clark. A. F., Scott, ( . R. and Wennberg. R. P.: Ahoent pyruvate decarboxylase in man: A cause of congenital lacticatcidesis Sicience, 187 : 1082 (1975).

12. (irover. W. D.. Aurbach. V. H. and Patel M. S. Biechemical sudies and therapy in subacute necrotising encephalopathy. J. Pediat. 34: 39) (1972).

1.3. Hauerth. J. (C.. Perry. T. I... Blats. I. P. Hansen. (i.. and Urquhart. N. Lacticacidesis in three sibs due to defects in hoth pyruvate dehydrogenase and e-ketoglutarate dehydrogenase complexes. Pediatrics, 58. 56t (1976)

14. Hohorst, H. J.: L(+)Lactate. In: H. U. Bergmeyer: Methods of Enzymatio Analysis. pp. 266-275 (Academic Press. Ne'u York. 1965)

15. Laurrell. $S_{. .}$and Tibbling. G.: Colourimetric microdetermination of free fatty acids in plasma. (Clin. (him. Acta, 16:57 (1967)

16. Linn, T. ( .. Pettit. F. H.. Hucho. F.. and Rece, I. J : ex-Ketoacid dehrdrogenase complexes. Xl. Comparative studies of regulatory properties of the pyruvate dehydrogenase complexes from kidncy. heart. and liver mitochondriat. Proce. Nitt. Acad Sci. U. S. A. 64: $227(1969)$

17. Linn. T. (C. Pelley. J. W.. Pettit. F. H. Hucho, F.. Randall, D), D... and Reed. 1.. J.: a-Keto acid dehydrogenase complexes. XV. Purification and properties of the component enzymes of the pyruvate dehydrogenase complexes from hovine kidney and heart. Arch. Biochem. Biophys.. 148: $327(1972)$.

18. Murphy, J. V': Efficiency of recommended therapeutic regimen in L.cigh', discase. Develop. Med. ( hild Neurol. 16: 362 (1974).

19. Pincus, H. J.. Itokawa, Y.. and (ooper, J. R.: Enzyme-inhibiting factor in subacute necrotising encephalopathy. Neurology. 19: $x+1$ (1969)

20. Pontremoli. S.: Fructose-1.6-diphosphatase. Methode Enzymol 9. 625 (1966)

21. Reed. I.. J.. and Willms. (. R.: Purification and resolution of the pyruvate dehydrogenase complex (Escherichia coli). Metheds Enzzmol. y. 247 $(1966)$

22. Reed. I.. J., and Willms. ( . R.: Pyruvate decarboxylane. Methods Enzmol. 4: $25 \times(1460)$

23. Robinson. B. H., and Sheruosd. Wf. (;.) Pyruvate dehydrogenase phosphatase deficiency: A cause of congenital chronic lactic acidosis in infancy. Pediat Rey 9. 935 (1975)

24. Rohinson. B. H... and Sherword. W. (;.: Development of pyruvate dehydro-

Copyright • 1977 International Pediatric Rescarch Foundation. Inc genase in the tissues of the rhesus monkey (Macaca mulatha). (In preparatiun.

25. Roche. $\Gamma$. F... and Reed. $1 .$. J.: Function of the nonidentical suhunits of mammalian pyruvate dehỵdrogenase. Biochem. Biophys. Res. Commun. 48: $840(1972)$

26. Rowhol, A... and Alleyne ( . A. ().: Regulation of renal gluconeogenesis hy calcium ions, hormones, and adenosine cyclic $3^{\prime}-5$-monophosphate. Biochem. J.. 1.74: $157(197.3)$

27. Sakurai, Y.. Itukuvonhi, Y.. Hamada, M. Hatyakawa, Y.. and koike, M. Mammalian alpha-ketodehydrogenase complexes. V'I. Nature of the multiple forms of pig heart liposimide-hydrogenases. J. Biol ('hem 245.4453 (1976)

2X. Shepherd, D.. and Garland, P. B.: ('itrate synthase from rat liver. Methods. Enzymol. 13:11(1960).

29. Sichert. G.: Citrate and lsocitrate. In: H. U. Bergmever: Methous in Fnzymatic Analysis. Pp. 318-323 (Acatemic Press. New York. 1965).

30. Swanson. M1.: (ilucose-6-phosphatase from liver. Methods. Enzymol., 2: 541 $(1455)$

31. Stromme, J. H.. Bonde. ().. and Moc, P. J.: Fatal lactic acidosis in a newhorn attributable to a congenital defect of pyruvate dehydrogenase. Pediat. Res.. 10:62 (1976).

32. Tang. T. T. Giond. T. A.. Dyke. P, R. Johmonn. (i. P. MicReadic, S. R. Sy. T., Lardy, H. A. and Rudolph, S. B.: Pathogenesis of Lecigh' encephatopathy. J. Pediat. 81: 189(1973).

33. Tityler, S. I., Mukherjece. ( ... and Jungats, R. I .. Studies on the mechanism of activation of adipose tissue pyruvate dehydrogenase by insulin. J. Biol. (hem.. 248: $7.3(1973)$.

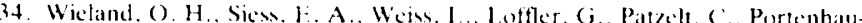
ser. R.. Hartmann. J.. and Schirmann, A.: Regulation of the mammalian pyruvate dehydrogenase complex by covalent modification. Symp. Soc Exp. Biol.. 27: $381(1973)$.

35. Williamson, D. H.. and Mellanhy. J.: $D(--)-\beta$-Hydroxybutyrate In: H. U. Bergmeser: Methesd in Fnzymatic Antlysis. pp. 459-46) (Academic Press. Nen York. 1965)

36. Worsley. H. E... Brookficld, R. W. . Iword. J. S.. Noble. R. I... and Taylur. W. H.: Iatcticacidosis with necrotising encephalopathy in two sibs, Arch. Dis. ( hildhered. 40: $492(1965)$.

37. This research was supported hy the Medical Research council of Canada (Cirant MRC MA-5473) and by the Weston foundation.

38. Reyuests for reprints hould be addressed to: B. H. Rohinson. M.D Department of Patediatrics. Universits of Toronto. The Hospital for Sick (Children, Toronto Ontario (c anada).

39. Received for publication January 10. 1977

40. Accepted for publication March 28, 1477

Printed in U.S.A

Alveolar macrophage lysosomal enzymes lysosomes oxidative enzymes phospholipids

\title{
Maturation of the Rabbit Alveolar Macrophage during Animal Development. II. Biochemical and Enzymatic Studies
}

\author{
IATA S. NERURKAR 'WM BARBARA J. ZIAII(SS. ANI) JOSIPH A. BELIANTI \\ Departments of Pediatrics. Microbielogy, and the Center for Interdisciplinary Studies of Immunology at

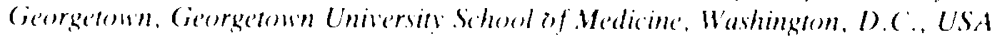

Summary

Alveolar macrophages (AMs) obtained from 1-day-old rabbits showed high levels of phospholipid, protein, DNA, and RNA compared to those obtained from 7-day-old, 28-day-old, or adult rabbits. The surfactant material released in alveoli during the perinatal period is extensively phagocytosed by AMs, and appears to be primarily responsible for high phospholipid content of these cells. The high protein, DNA, and RNA levels of A.Ms may result from phagocytosis of cellular debris.
Of the six lysosomal enzymes of AMs studied, acid phosphatase (AP) and lysozyme activities showed a decline in the first postnatal week. In AP this was followed by no significant change. A steady rise in lysozyme activity after the seventh postnatal day was observed. The activities of cathepsin $D$ and DNase did not show significant changes, whereas $\beta$-glucuronidase and RNase activities of AMs increased significantly within the first postnatal week.

The activities of glucose-6-phosphate dehydrogenase (G-6PD), 6-phosphogluconate dehydrogenase (6-PGD), lactate de- 
hydrogenase (I.DH), and malate dehydrogenase (MDH) in AMs appeared high in AMs of 1-day-old animals compared to other time periods studied. Following a significant decline in these activities in the first postnatal week, a peak was observed in the activities of ( $;-6-P D), 6-P(; D)$, and $I . D H$ at 28 days.

\section{Speculation}

A high concentration of phospholipid in AMs obtained from newborn animals suggests that $A M s$ play an important role in the removal of excess surfactant from the newborn lung. A relative increase in hexosemonophosphate shunt activities over glycolytic or Krebs cycle activities after birth and an increase in lysozyme activity after the first postnatal week may contribute to the capacity of $A M$ s to kill and degrade the microorganisms.

Alecolar macrophages comstitute the major phagecytic defense of the lung. Although considerable reseated has been directed in the past to the study of the morpholegy (17.39. 44). $51)$ enzomology $(16,18)$. metabolic hehavior $(3,50,53)$, and function (10. 14. 36) of AMs in adult animats. little is kmown about their maturation during animal develepment.

As described in the previous report $(6.5)$. a dramatic increase in the number of lavagable AMs of rathets was observed during the perinatal and postnatal periods. Prominent morpholegio changes observed during this period included decreasing glecegen stores. accumulation of lipid droplets. increatse in the prominence of the (iolgi apparatus, and an increase in the amount of rough endoplasmic reticulum and the mumber of lysosomes and mitochondria. In the present report several fiochemical parameters of the rabhit $A M$ were insestigated during animal development with a specific emphasis on the study of the development of lysosomal and oxidatise ensme activitics. both of which are known to participate in the metatbolic functions of ANs (3).

\section{MATERIALS ANI) METHI()DS}

\section{ANIMINS}

Alseolat macrophages were obtaned from New Kealand white rabhits of both sexes (B and $H$ Rabbitry. Rockville. Md.). (iroups of $3-22$ rabhits of eitch of the following ages were employed: 1 day (6-20 hr): 7 and 28 days after birth: and 90 or more dass after birth (considered addult).

\section{ISOIATION ()F MARCR()PHA(itS}

AMs were obtatined by tracheohronchial lasage an described in the previous report $(6.5)$. In order to obtain a sufficient yuantity of cells, suspensions from littermates of the 1 -day-old and 7-day-old animals were pooled. After lavage, the cells were

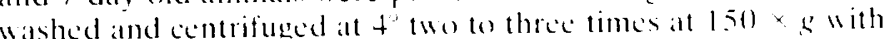
Krebs-Ringer phosphate buffer. pH $7.2(62)$. modified to contain $1.5 \mathrm{mM}$ (al ". The cell suspension was adjusted to at final concentration of $5-10 \times 10^{\mathrm{fi}}$ (c)tls/ml. The viability of cells in suspension was alwats more than 95", 1 hen atsalyced by trypall blue exclusion method and alveolar macrophages comstituted approximately 95"; of the cells in suspension. Aliquots of these suppensions were removed for the measurement of phopholipid. protein. DNA. and RNA and the rematinder was sonicated for two 15 -sece intervats at 1.5 kilocycles/sece employing a Biesonik 11 sonicater (67) for determinations of several enzyme alctivitics.

The following reagents emplosed in the present studies were obtaned from Sigma (bemical company. St. I ouis. Mo.: calt thymur DNA (type 1); yast RNA (type XI); p-nitrophenyl phosphate; $p$-nitrophenyl- $\beta$-I)-glucuronide; bovine hemoglohin

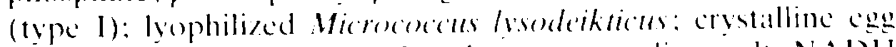
white lysozome: glucose-(1-phosphate monosodium salt: $\mathrm{N}$ :NDH (grade V) and oxalatectate (grate l)

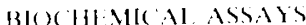

Phospholipid Determination. Phoupholipide were extrateded an decribed be Folch et al. (28) and phosphorus was yuantitated

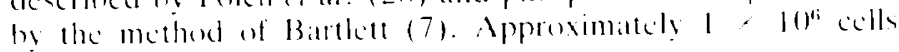
vere used lor the ansals.

Protein Determination. Protein was determined by the methed

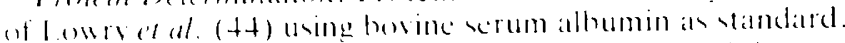

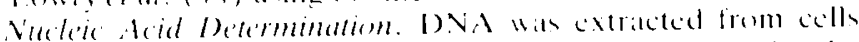
by the method of lewat and Kelley $(+1)$ and measured by the methes of Burton (i.3) with orernight color development at 37 . Purificd calf themun DNA was uned an standard. RNA It

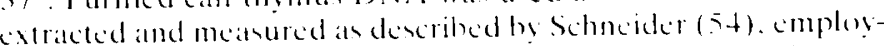
ing veast RNA as a standard. Approximately 1 × 10 fiells were used for cacth of these assays.

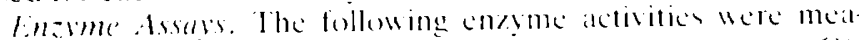
sured: acid phomphatase (AP). $\beta-1)$-glucuromidase $(\beta-(i)$.

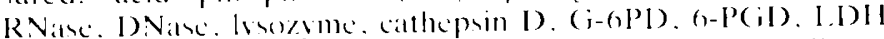

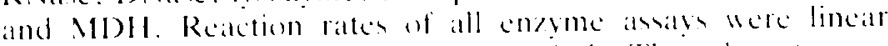
throughout the ypecificd incubation periods. The substate concentrations were optimal. Fonsme activities were proportional 11) the protein concentration used within the upecified range and Here expresed an units $2.5 \times 10^{\mathrm{t}}$ colls.

Acid Phosphatase (I:C 3.1 .3 .2$)$. The ansaly mixture for $A P$ contained at final concentration of $1+10 \mathrm{mM}$ sodium acetate huffer (pH 5.01$)$. s m.11 p-nitrophenyl phosphate and $0.1-0.2$ me macrophage protein (6). Incubations lere performed in total volume of $2.0 \mathrm{ml}$ for $15 \mathrm{~min}$ at 37 . The reaction 1 ats stopped by the addition of ice-cold I M Tris-Hed huffer (pll s.5) containing $0 .+\mathrm{N} \mathrm{K.HP(),} \mathrm{as} \mathrm{suggested} \mathrm{by} \mathrm{Torriani} \mathrm{(61)}$ and the extinction measured at $420 \mathrm{~mm}$.

$\beta-l)$-(jlucuronidase' (E: 3.2.I.3/). $\beta$-(; was measured using p-nitrophenv- $\beta-$ D)-glucuronide as substrate (6). The assaty mixture contained at a final concentration $100 \mathrm{mM} \mathrm{Na}$ atectate buffer (pH $5.69 .6 .8 \mathrm{mM}$ glucuronide. $0.1-0.2$ mg macrophatge protein in a total bolume of $1.1 \mathrm{ml}$. Incubations were carriced out for $15-30$ min at $37^{\circ}$ and the reation was stopped hy addition of $1.5 \mathrm{ml} 0.5 \mathrm{~N}$ sodium carbonate-bicarbonate buffer as dencribed hy Barrett $(6)$ : the ahsorbance wats measured at $+20 \mathrm{~nm}$

(athepsin I) (le( 3.t.4.23). The assaly for cathespin D) was based on the method deseribed by Anson (2). Purified hovine hemoglobin in $0.025 \mathrm{~N} \mathrm{H(1)}$ at a final concentration of $2 \%$ was incubatcd with $0.1-1) .2 \mathrm{mg}$ macrophage protein for $30 \mathrm{~min}$ at $37^{\circ} \mathrm{in}$ an assat volume of $2.11 \mathrm{ml}$. The reatetion was stopped by the addition of $2.0 \mathrm{ml}$ ice-cold $5 \%$, trichloroatcetic atcid. Solubilized protein degradation products were meanured at $280 \mathrm{~nm}$ alter proper dilution of the filtrate.

Ribonuclease (I:C 2.7.7.10). The assay for RNase consisted

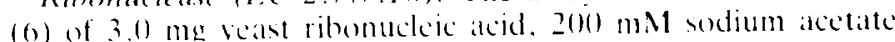
buffer (pH $5.0 \%$. and $0.1-0.2 \mathrm{mg}$ matcrophage protein in a final wolume of $2.0 \mathrm{ml}$. After incubation for $30 \mathrm{~min}$ at $37^{\circ}$ the radetion was terminated by the addition of $2.0 \mathrm{ml}$ perchloric

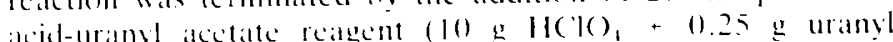
acter hrought to 100 ml with watter): after standing for fol min at $t$ the imsoluble precipitate was discanded by centrifugattion. the supernatant was diluted. and the abserbance was

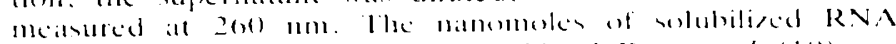
products were calculated as described by ded ouse at al. (19).

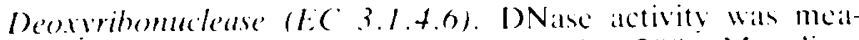
sured (o) as follows: 1.5 mg call themus D) N : $200 \mathrm{mM}$ sodium acetatc buffer (pH 5.0$)$ containing $200 \mathrm{mM}$ potassium chloride; and $0.1-0.2 \mathrm{mg}$ macrophage protein were incubated for $30 \mathrm{~min}$ at $37^{\circ}$ in at final volume of $2 \mathrm{ml}$. The reaction was then stopped by addition of $2 \mathrm{ml}$ ice-cold $100^{\circ} ;(\mathrm{w} / \mathrm{N})$ perchloric acid. After allowing to stand for $20 \mathrm{~min}$ at $4^{\circ}$. the insoluble precipitate was removed hy centrifugation and the absorbance of the supernattant was measured at $260 \mathrm{~mm}$. The nanomoles of nucleotides liberated were calculated ats described hy deDure det (19).

L.sozime (EC 3.2.1.77). Lysozyme ativity was determined according to the method of Shugar e't al. (55) and l itwalck (42) with minor modifications. Fo at $2.5-m$ suspension of lyophilized 
Micrococcus lysodeikticus $(10 \mathrm{mg} / 100) \mathrm{ml})$ in $60 \mathrm{mM}$ potassium phosphate buffer. pll 6.2.0.1 ml lysogsme solution (4-25 units egg white lysogme) or $0.1 \mathrm{ml}$ macrophige homogenate containing $0.05-(0.2 \mathrm{mg}$ protein were added. The change in absorbanco at $4.50 \mathrm{~nm}$ war mealsured immediately and was followed up to 1-2 min. A unit of lysesme was defincel at that amount of cinzyme which caused a reduction in the absorbance of a Micrecoceus suspension by 0.001 at +50 mom in 1 min at pla 6.2 in $2.6 \mathrm{ml}$ reaction mixture and using a light path of $1 \mathrm{~cm}$.

Glacose-6-phosphate Dehydrogenase $(E($ ' 1.1 .1 .49$)$. (j-6-PI) was measured by the method of Marks (45). The assats mixture contained $50 \mathrm{mM}$ glyeglglycinc buffer (pH 7.5$) .20 \mathrm{mM} \mathrm{Mg}(\mathrm{l}$. . (1.1 mM NADP+. $2 \mathrm{mM}$ glucose-6-phosphatc (monosodium salt). and (1.1-0.2 mg macrophage protein in a final volume of $2.5 \mathrm{ml}$. The increase in aboubance was measured at $3+1) \mathrm{mm}$ (molar extinction coefficient of NADPH at $340 \mathrm{~nm}-6.22 \times$ $\left.10^{4} \mathrm{~cm}{ }^{2} \mathrm{~mol} \mathrm{l}^{1}(3.3)\right)$. The unit of activity was described as that amount of ensyme which will oxidise i nmol glucose-f)-phosphate to 6-phosphogluconatemin at $\mathrm{pH} 7.5^{\circ}$ at $25^{\circ}$ in the presenceof $\mathrm{V} \backslash \mathrm{XIP}$.

6-Phosphogluconate Dehydrogenase (t:( I.1.1.4.3). The method employed for the assaty of $6-P(i D)$ ad identical to that of (i-6-PD except that 6-phosphogluconate was used as substrate $(+6)$.

Lactate Dehydrogenase $(E)($ I.1.1.27). The method emploved for the assay of L.DH was similat to that of Bernstein and Everse (9). The assay mixture contaned $1001 \mathrm{~m} . \mathrm{M}$ sodium phosphate buffer (pH 7.5 ). $0.09 \mathrm{mM}$ NADH. $0.67 \mathrm{mM}$ sodium pyruvate and 0.1 and 0.2 mg materophage protein in a final volume of $3.0 \mathrm{ml}$. The decreatse in absorbance was measured at $3+1) \mathrm{nm}$ against a reference cusette containing no conzeme protein (molar extinction coefficient of NADll at $3+0 \mathrm{~nm}$ $6.22 \times 1\left(0^{6} \mathrm{~cm}=\mathrm{mol} 1 \mathrm{l}(3.3)\right)$. A unit of activity was defined as that amount of enzyme which will reduce 1 nmol pyrusate to lactate/min at $25^{\circ}$ in the presence of $\mathrm{N}$ ADH

Malate Dehydrogenase (EC 1.1.1.37). The method of Dupourque and Kun (2.3) was used for the assaty of MDH with some modifications. The assay system consisted of $100 \mathrm{mM}$ sodium phosphate buffer (pH $7.59 .0 .09 \mathrm{mM}$ NAI)H. $7.5 \mathrm{mMl}$ oxalatectate, and $0.1-0.2 \mathrm{mg}$ emzeme protein in a final colume of $3.0 \mathrm{ml}$. The reaction was followed by measuring the decrease in aborbance at $340 \mathrm{~nm}$. The unit of activity was defincd an that amount of engme which will reduce 1 mmol oxalacetate to malate/min at $25^{\circ}$ in the presence of $\mathrm{NADH}$.

\section{STATISTC AL ANATSLS}

The results of the entyme assats are presented as mean

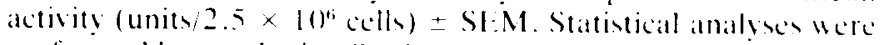
performed by employing Student is test (22).

\section{RI:SL:ITS}

The results of phospholipid-P. protein. DNA and R.NA determinations of $A . M$ s obtained from animals at different postnatal ages are shown in Tahle 1 . It mat he seen :hat the highest concentrations of each of these constituents were present in the AMs of newborn animals. after which a gradual decline was observed in later age groups. No significant variations in any of these constituente in AMs were sherved after 7 das. An approximately 20-fold excess in the amount of phospholipidP was oberved in A.Ms from newhorn animals when compared t1) A.Ms from adult amimals. Thin correlated with the latge numbers of phospholipid inclusioms seen at this time (6.5). The protein concentration of $A M \mathrm{~S}$ from newhorn animals was about 1.6-fold higher than that obtained at other perieds. The D.VA concentration measured in A.M from newborn animals Was approximately 2-fold higher than that ohtained at later time periods. The R.NA content of AMs showed similar changes with leve approximately 5 -fold higher at birth than all later periods.
Table 1. Postmatal changes in concentrations of phospholipid-P. protein, DNA. and R.VA of rabbit alverolar macrophage's

$$
\begin{aligned}
& \text { Age. Phospholipid-P. Protein, IDNA. RNA. }
\end{aligned}
$$

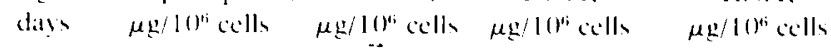

$$
\begin{aligned}
& 121.73: 8.81 \quad 395 \pm 44 \quad 24.8 \div 4.0 \quad 127.2 \pm 44.0 \\
& \begin{array}{lllll}
(4)^{2} & \text { (11) } & \text { (4) } & \text { (3) }
\end{array}
\end{aligned}
$$

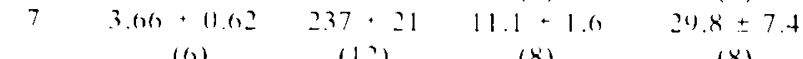

$$
\begin{aligned}
& 28 \quad 1.83+0.34 \quad 232+15 \quad 11.6 \pm 0.9 \quad 24.0 \pm 5.0 \\
& \begin{array}{lllll}
(4) & (17) & (4) & (4)
\end{array} \\
& \text {.90 } \quad 1.15 \div 0.099 \quad 250+14 \quad 10.8 \pm 0.3 \quad 23.3 \pm 3.0 \\
& \text { (8) } \quad(22) \quad \text { (4) }
\end{aligned}
$$

1 mean \pm S1:M

"Figures in parentheses indicate the number of experiments performed

The pentuatal changes in atcivities of lysosmal hydrolanes of A.M are illestrated in Figure 1 . A significant decline in alctivity of $\mathrm{AP}(P<0.05)$ of AMs Was observed during the first postmatal weck after which no significant changes were scen. $A$ similar decline in the intial activity wan seen with lworsme ( $P$ 0.051 . Which was followed by a significant steady increatse ( $P$ ) 0.05) up to the adult state. No significant changes in cathepsin D) and DNane aletivities were seen during all the time periods studied. Whereats the $\beta$ - $(i$ and RNase atctivities of AMh showed a significant initial increalse $(P \cdot 0.05)$ in the first postnatal weck followed hy no change up to the adult period.

The postnatal changes in oxidative enzyme alctivitices of AM are illustrated in ligure 2. After a significant intial declinc in

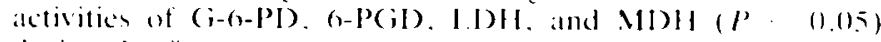
during the first postnatal weck, a peak in activities of (i-6-PD) 6-P(iD). and I.D)H wat observed at 28 days. No further significant changes were ohecred in the activitios of $(;-6-P D)$ and MDH but significant declenes in the activities of $6-P(i)$ and 1.1)H were observed between 28 ditys and the adult period ( $P$ $(1.05)$.

\section{DIS( $\operatorname{lisin}() \pi$}

The results of the present insestigations reveal that $A M s$ undergo profound changes in certain biochemical comstituents and emsme activities during posmatal periods. The mammalian lung exhibit. significant biochemical (4. 27.34. 35) and structural (11. 12. 60) changes during the perinatal peried in response to covirommental changes and these changes may be reflected in these exhibited by AMs.

During later periods of gestation at rather matked increase in production of multilamellar bodies aceurs in lung. which is followed hy release of these bodies into the alveroli at the onset of breathing $(34)$. These hodes form the source of surfactant matcrial. which consists primatrily of dipalmitoyl lecithin, along with several other phospholipids. some proteins. and minor components such as carbohydrates and nucleic alcids $(35)$. In preliminary studies in our laboratory. the accllular fraction of the lung latage hats been shown lo comsist mainly of lamellar and other surfactant-related melin structures derived from type II penumecyter $(6+)$ : imilat structures have been shown to be extensively phatgecytesed by $A M$ shtained in the perinatal peried $(6.5)$. In the present study a 20 -fold excess of phospholipid material was oberved in AMs from 1-daty-old compared to adult animals. further supporting the suggestion that AMs platy a major role in clearance of surfactant material $(48,49$. $65 \%$. In addition. a portion of the phospholipid of $A M$ s of newborn animals may also arise from de notos membrane ynthesis by $A M$ s during phatgocytosis (25.26).

Two possibilitice exist to explain the high protein content in the AMs of newborns: (I) phagecytosis of surfictant material and cellular debris. of (2) de nove synthesis similar to that 

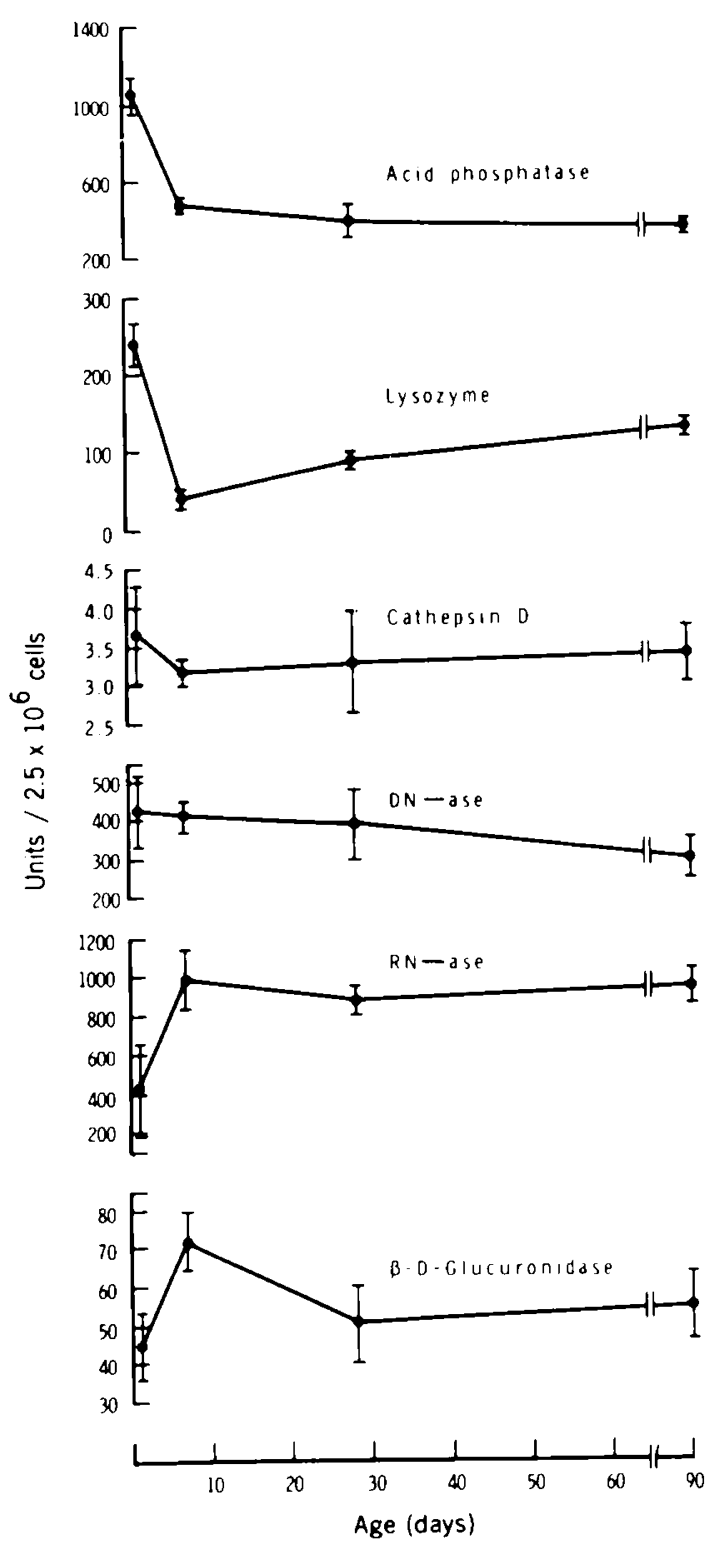

Fig. 1. Activities of lysosomal enzymes of alveolar macrophages obtained from rabbits of varying ages.

following inflammatory stimuli (24). The finding of a large number of phagosomes seen in the newborn AMs (6.5), which decrease in size within the first postnatal week. supports the first of these possibilities.

The DNA concentration of AMs from 1-day-old animals was similarily elevated. A large amount of phagocytosed material. epithelial cells. and other debris could in part account for this increase. The acellular fraction prepared from the lung lavage from 1 -dav-old animals showed a significant amount of DNA unlike a similar fraction obtained from 28 -day-old animals in which no DNA was detected. This finding lends further support to the possibility that a portion of DNA of AMs from 1-day-old animals was derived from their surrounding debris. Alternatively. proliferation of $\mathrm{AM}$ precursors in the lung interstitium appears to occur before birth (1) and it is possible that eclls in G.2 phase with diploid content of DNA may enter the alveoli during the perinatal influx of cells $(6.5)$.

The similarity between patterns of changes in content of RNA and other constituents of AMs studied suggests that the high level of RNA of AMs from 1-day-old animals may be also derived from phagecytosed debris. The elevated level of RNA at this time may also indicate a preparatory step for the formation of RER which was seen to be increased ultrastructurally $(6.5)$ during first postnatal week and thus would equip for and facilitate protein synthesis. Monocytes and macrophages have heen shown to be capable of active RNA $(14.56 .57)$ and protein synthesis $(15,40,43)$.

() the six lysosomal enzymes studies in AMs. AP. and Jysozyme showed a significant decrealse in their activities between the first and seventh postnatal days. The change in $A P$ activity may be more apparent than real, since this activity has been shown to be present in the lamellar inclusions $(5,21,29)$ which are phagocytosed in great abundance by $A M$, at birth (6.5). In a separate set of experiments we have demonstrated the presence of $A P$ in the accllular fraction from lung lavages from l-day-old animals. In contrast to the other lysosomal enzymes. the lysozyme activity of AMs appears to change in a unique manner. A decline was observed in this activity between the first and seventh postnatal day which might be due to accelerated release of this enzyme. In support of this possibility. AMs or peritoneal macrophages from adult animals have been shown to secrete large amounts of lysozyme. keeping only moderate amount of cell-associated enzyme (30. 32) and lysozyme activity shows almost parallel changes in serum in the first

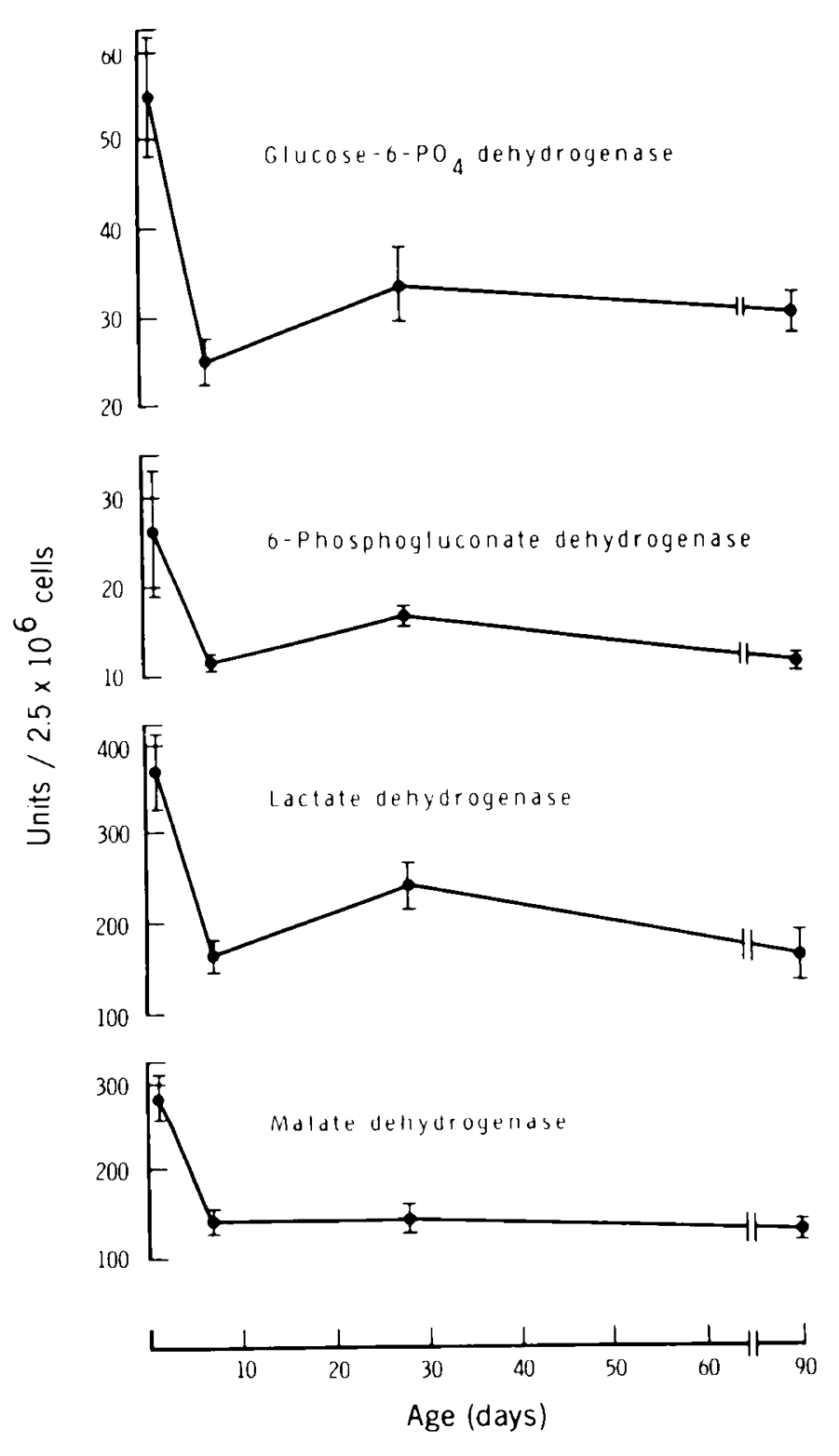

Fig. 2. Activities of axidative enzymes of alverolar macrophages obtained from rabbits of varying ages. 
postnatal week (37). In the present study, the steady increase in lysozyme in AMls after the seventh postnatal day may be related to the formation of new lysosomes (6.5). Unlike the activities of cathepsin D and IDNatse. which did not show significant changes. $\beta$ - $B$ and $R N$ asce activities of $A M$ s increased significantly within the first postnatal week; this may he related to the appearance of lysersomal granules during this period (65). Previous work from other laboratories has suggested the existence of subpopulations of lysosomes in AMs $(58.59)$ and may explain the selective increase in the activities of only some of the lysosomal enzymes measured in the present studies. Although an increased number of lysosomes was observed morphologically in the subseyuent time periods (between the 7 th and 28 th postnatal days). there were no statistically significant increases in the activities of lysosomal enzymes except in the case of lysozyme (Fig. 1). This may suggest redistribution of lysosomes through the process of division and fusion rather than increased synthesis of lysosomal enzymes (20). Finally. a full spectrum of lysosomal enzymes may not be present in granules visualized by electron microscopy.

The activities of four oxidative enzymes studied. ((i-6-PD). 6$P(D), L D H$, and $M D H)$ of $A M$ from $l$-day-old animals appeared to be high compared to the other time periods studied and may be related to the available substrates and the metabolic and phagocytic activities of these cells. The high glyeogen utilization. characteristic of the energy metabolism of the tissues of the newborn animals. Was also seen in AMs of the newhorns: a depletion of prenatally accumulated glveogen stores and simultaneous change from glycolytic carbohydrate utilization. presumably to fat oxidation, was observed $(65)$. We have also reported previously the appearance of lipid droplets in AMs during the first postnatal week together with an increase in the number of mitochondria $(65)$. a major site for fat oxidation. It thus appears that glycogen provides an endogenous substrate pool for glycolytic and hexosemonophosphate shunt (HMPS) activities. The higher activities of LDH. ( $;-6-P D)$, and 6-P(iD in AMs at birth might be a result of the high concentration of the substrate for these enzymes and may in turn facilitate the utilization of the substrate for the generation of energy. Moreover. the high phagocytic load at hirth $(6.5)$ may also contribute to the heightened activity of these enzomes. and as a conseyuence generate additional energy and NADPH required during the phagocytic event. Finally. a nonspecific activation of HMPS of macrophages by surface-active agents, presumahly related to the perturbation of plasma membrane, has been reported (31) Heightened activities of (i-6-PI) and 6-P(iD) of newborn AM residing in surfactant-enriched environment in the lung may be related to similar phenomena.

Although the major pathwas of carbohsdratc metaholiom are functional in $A M$ a de different time periods studied. the is relative contribution to energy metaholism appears to differ at varying ages. After adjusting for glacose cyuisalents metabolized ration of activities of $\mathrm{I} . \mathrm{D}) \mathrm{H} / \mathrm{(i-6-PI)}$ and $\mathrm{MI}) \mathrm{H} /(\mathrm{i}-6-\mathrm{PI})$ were 3.4 and 1.7 . respectively. at birth and decreased to 2.7 and 1.4. respectively, in the adult period (Fig. 2), thus indicating a relative increase in the HMPS activity in the addult period. This relative increase in activity of HAPS maty be in response to the environmental challenges these cells enceunter. Increatsed metaholism via HAPS during active phagecotosis and killing ot batederia hate been described previously by Mrwih and latan (47) and Romi and coworkers (52.53). Although the vignificance of the present finding is vet unclear. these anpear similat (1) the changes in HMPS conzmes activities reported in human neutrophik $(8.6,3)$. It is tempting to speculate that these changes maty be correlated with the develepment of hactericidal activity of the AMs during maturation (6o).

\section{(oncoliston}

AMs ebtaned from rabbits of varsing age were studied for their phospholipid, protein. DNA, and $R N A$ content. $A$ great excess of phospholipid in $\mathrm{A} . \mathrm{M}$ s at birth indicates the role of $\mathrm{A} . \mathrm{M}$ in remonal of surfictant from the lung. The relative increase in HMPS activities ower other pathwas of carbohydrate utilization wherved hetween the neonatal and adele periods and lysosme activity after the first postnatal week mas be in response to the stimuli the A.Ms concounter and maly contribute to their capacity to destros microorganisms. The variathility in changes in lyoser mal enzymes of $A M k$ between the neonatal and adult periods maty be indicative of subpopulations in the lyosomal gratnules.

\section{RIFIRFN(ISS ANI) NOTHS}

1. Adamon, 1. Y. R.. and Bowden. 1). H.: Derivation of tepe I epithelium from type 2 cells in the develuping rat lung. Lath. Insest.. 32: 736 (1975) 2. Amon, if 1 . : The estimation of athepsin with hemoglohin and the partial purification of cathepsin. J. (ien. Physiol.. 2(1):56,5(19.37).

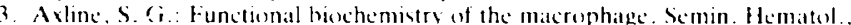
$7: 1+2(197(1)$

4. Azeopardi. A.. and Thurbeck. W. M.: The oxidative ensyme pattern in developing and adult mice and adult rabbits. Lat. Invest. $16: 706(1967)$

5 Balis, J. I'.. and conen. P. .... The role of alveolar inclusion hedies in the

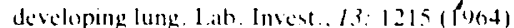

6. Barrett, A. J.: In: I. I. Dingle: I yosomes. A lahoratory Handbonk. p. th (North Holland Publishing (o.. Amsterdam-london, 1972).

7. Bartlett. (;. R.: Phosphorus assay in column chromatography. J. Biol. (hem. 2.34: the (1950).

8. Bellanti. J. A.. Cantz. B. ... Yang. M. (.. Thadden. H. Y.. and Schlegel. R. I.: Biochemical changes in human polymorphonuclear leukocytes during maturation. In: J. A. Bellanti and D. H. Datyten: The Phagecvtic (cill in Host Resistance, p. 321 (Raven Press. Hewlet, New York. 1975)

9. Bernstein. 1.. H.. and fverse, 1.: Determination of the isorneyme levels of latctate dehydrogenase. Methods lin/ymol.. $4 / B: 47(1075)$

11). Bowden. D. H.: The alveolar macrophage and its role in toxicologes. ( R( (rit. Rev. Toxicol.. 2: $195(197,3)$

11. Burri. P. H.: Pontnatal growth and maturation of the lung. ('hest. 6? (Suppl.) 2S (1975).

12. Burri. P. H.. Ibaly. J.. and Weibel. 1. R.: Ihe posenatal grenth of the rat lung. I. Morphometry. Anat. Rec.. 178: 711 (1974)

13. Burton. K.: A study of conditions and mechanism of the diphenvlamine reation for the colorimetric estimation of deoryribonucleic acid Biochem. J., 62: $315(1956)$

14. Cohn. Z. A.: The structure and function of monocyles and macrophages Advan. Immunol. 4: $16.3(1968)$

15. Cobn. 7. A.. Fedorko, M. F... and Hiruch. J. (i.: The in vitro differentiation of mononuclear phagecytes. $V$. The formation of macrophage lyouromes. J. Hxp. Med.. 123:757(1966)

1h. Cohn, Z. A.. and Wiener, F.: The particulate hydrolases of macrophages. I Comparative enzymology, isolation and properties. J. Fxp. Med., I/8 (1) $(1)(1363)$

17. Collet. A. J.: Jine structure of the alveolar macrophage of the cat and medifications of its cytoplasmic components during phagecytosis. Anat Rec..167: 277 (1970)

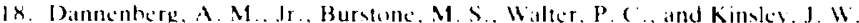
A histochemical study of phagrevtic and ensmatic functions of rabbit mononuclear and polymorphonuclear exudate cells and alveolar macrophages. 1. Survey and quantitation of enzymes and states of cellular activation. J. (ell Biol., 17: $465(196.3)$

19. deDure. C.. Pressman. B. C.. Cianctto, R. Wittlitux. R. and Appelmams. F.: lissuc fractionation studies: Intracellular distribution patterms of enaymes in rat-liver tissue. Biechem. J.. $\theta 0: 6(14)(1955)$

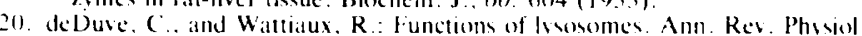
$28: 435(1965)$

21. DiAugustone, R. P.: I ung concentric haminar organelle, hydrolase activity and componitional analyis. J. Biol. (hem.. 240:584(1674)

22. Dixun. W. J.. and Massey. F. J.Jr.: Intruduction to Statistical Analysis, Id

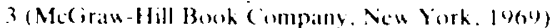

23. Dupourgue. D)., and Kun, F.: (vtoplasmic and mitochondrial malate dehp-

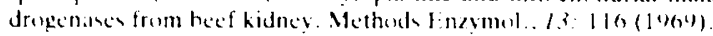

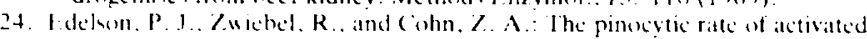
matrephages I Kxp. Med.. 142:115011075).

$2 \therefore$. Whach. P.: Stimulation of lecothion sinthess from medium lysolecithin during phagocolosis. J. (lin. Invest. fo: $1052(1967)$

26. I lshach. P.: Increased synthesin of phompholipid during phagocylesis. J. ( lin Invert., 47: $2217(106 x)$

27. A terly. I. R. Standen. A. ( .. and Pearsen. B.: Hodrolytic ensemes in the

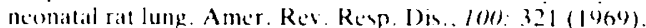

28. Folch. I. Iaes. M., and Sloanc Stanley. (;. H. A simple method for the isolatton and purificattion of total lipide from animat tisuces. J. Bisl. ( ham.. 226: $407(1957)$

29. (ioldfischer. S Kikkawa, $Y$ and Hoffman, I. The demonstration of acid hydrolase activities in the incluson bodies of type II alseolat cells and wher lyosemes in the rabbit lung. 1. Histochem. (ytochem. 10: 102 $(1968)$.

30. Ciordon. S.. Todd, J., and cohn. K. A.: In vitro wnthesis and uecretion of

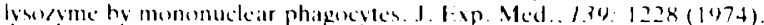

31. Graham. R. C...Ir. Karnovsky, M. J.. Shafer, A. W.. (ilam, I. A.. and 
Karnovshy. M. I..: Metabolic and morphological ohervations on the effect of surtiac-active agente on leukecyter. J. (cill Biol.. 32: 629)(1967)

3) Heise, $\mathrm{R}$ and Myrvik, (). N : Secretion of lysoryme by rabbit alveolar macrophages in vitro. J. Reticulocondethel. Soc.. 4: $510(1967)$.

33. Horecker. B. I... and Kornberg, A.: The extinction coefficients of the reduced hand of pyridine nuclectide. J. Biol. (hem.. 175: 38.5 (194K)

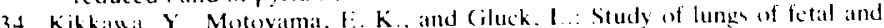
newborn rabbits. Amer. J. Patbol.. 52: 177 (196x).

35. King, R. J.. and (lements, J. A.: Surface active materials from dog lung. Il composition and phvisulegical correlations. Amer. J. Physiol. 22.3: 715 (1) 122 ).

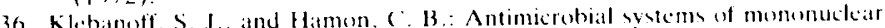
phagecytes. In: R, vanfurth: Mononuckear Phagnevites, p. 507 (Blackincll Scientific Publications. ()xford 1975).

37. Klockars, M. Adinolfi. M. ( . and ()serman. E. F.: Ontogeny of lysozyme in the rat Proc Soc Lxp. Biol. Med.. 145: 6(14. (1974)

38. Krasno, J. R.. Knelson, J. H.. and Dalldort, F. (;.: (hanges in alverelar lining with the onset of breathing. Amer. J. Pathol. o6: 471 (1972)

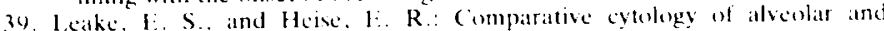
peritoneal macrophages from germ frec rats. Advan. Hxp. Med. Biol.. I: $133(1966)$

40. 1.effingwell. ( . M.. and 1.om, R. B.: Protein biosynthesis by the pulmonary alveolar macrophage: (omparison of synthetic atetivity of suppended cell and cello on surfices Amer Rev. Resp. Dis.. /12:349) (1975)

+1 Leysa A Jr. and Kelley. W. N.: Measurement of DNA in cultured human cills. Anal. Binchem. 62: $173(1474)$

42. Litwack. (i.: Photometric determination of lysozyme activity. Prox. Soc fixp. Biol Med 89) $401(1955)$

43. low R. B. Protein hiosynthesis by the pulmonary alveolar materophage conditions of assay and the effect of cigarette smoke extracts. Amer. Rev Resp. Dis. I/10: \$66 (1974)

44. Lowry, (). H. Rouchrough. N. J.. Farr. A. 1... and Randall. R. J.: Protein measurement with the Folin phenol reagent. J. Biol. (hem., l4.3: 26.5 (1951)

45. Marks. P. A.: (ilucose-t)-phesphate dehydrogenase-( linical atspects. Methads Enzymol.. 9: 1.31 (1960)

to. Marks $P$ a 6-Phosphogluconate dehydrogenase - clinical aspects. Method I:nzymol. 9: $1+11(1966)$

47. Myrvik, (. N... and Evans, I). (;.: Iffect of Bacillus (almette (iuerin an the metaholism of alveolat macrophages. Advan. Exp. Biol. Mcd.. I: 20.3 $(1967)$.

48. Naimark. A : Cellular dynamies and lipid metaholism in the lung. Fed. Proce 32: $1967(197.3)$

44. Nichols. B. A.: Normal rathit alveolar macrophages. I. The phagecytoss of tubular myelin. J. Fxp. Med.. 144: 9)(19676)

50 Oren, R. Farnham, A. F... Satito, K. Milutsky, E... and Karnowky. M. I Metatolic patterns in three types of phagecytizing cells. J. (cill Biol.. I $4 \times 7(196.3)$.

51. Pratt, S. A.. Smith. M. H. l.adman. A. J., and Finley, T. N.: The ultastructure of alveolar macrophages from human cigarette smokers and nomemokers lab. Invest. 24:331(1971).

(opvright 19077 International Pediatric Research Foundation. Inc
52. Romeo, 1). Zathucchi, (i.. Marzi. T., and Romi, F.: Kinetic and enzymatic features of metabolic stimulation of alveolat and peritoneal macrophages challenged with bacteria. Ixp. (ell Res. 78: 423 (197.3)

53. Romi. F.. Zabucchi. ( 3 .. and Romeo, D). Metabolism of phagecytosing mononuclear phagocytes In: $R$. vanfurth: Mononuclear Phagecytes. $p$. 41 (Blackwell Scientific Publications, ()xford, 1975).

54. Schncider. W. D.: Determination of nucleic acids in tissues by pentose analysis. Method Inzymol...3: $680(1957)$

55 chupar. D). The meisurement of lysozyme activity and the ultraviolet in Bione Acta, $8: 302$ (1952)

56. Soderberg, L.. S. F.. Ruhin, A.. Kuchler. R. J.. and Solotorovishy. M. Ribonuclecic acid synthesis in mouse peritoneal macrophages in vitro. (ell Immun.. 3: 672 (1972)

57 Soderberg. L. S. F.. Tewari, R. P.. and Solotorowery, M.: Ribonucleic acid sunthesis in normal and immune macrophages after antigenic stimulus. infect. Immun., 1.3: 1531 (1976)

is Sorber. W. A. I eake, I. S... and Myrvik, () N.: (umparative densities of hydrolase containing granules from normal and $\mathrm{BC}(\mathrm{i}$-induced alventar mitcrophages. Infect. Immunol. 7: $86(197,3)$

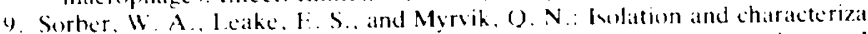
tion of hydrolase containing granules from rabhit lung macrophages. J Reticulendothel. Soc.. 16: 184 (1974)

ol Sorokin, S.: Histokhemial events in the developing human lungs. Actit Anat $40: 105(1900)$.

61. Torrian. A.: Influence of inorganic phosphate in the formation of phosphatase by tscherichia coll. Biochim. Biophys. Actia, 38: $460(1960)$

2. Limbrit IV II Burris, R H and Stauffer, J. F.: Manometric ans Biochemical Techniques, \&d. 5. p. 144 (Burgess Publishing Company. Minneapolis. 1472)

63. Vetrellar. M... and Barthelmati. W.: Variations of enzeme activitice in leuker cte in relation to age In 1 . (ierlach, K. Moser. F. Deutsch, and W. Wilmanos: Erythrocytes. Thrombocytes. leukncytes: Recent Advances in Membrane and Metabolic Research. p. 405 (Thicme. Stutegart, 1973)

64. Zeligs. B. J.: Unpuhlished data

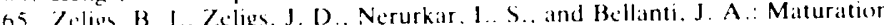
of the rabbit alveolar macrophage during animal development. I. Perinatal influx into alveoli and ultrastructural differentiation. Pediat. Res.. 1/: 197 (1)77).

66. Zelige B I. Nerurkar L. S... and Bellanti. J. A.: Maturation of the rabhit alcolar macrophage during animal development. III. Phagerytic and hactericidal functions. Pediat. Res. 11: 1208 (1977)

67. Biosonik 1I. Bronwill Scientific. Ruchester. New Yorh.

68. The authors wish to thank katherine (". Hill for her assistance

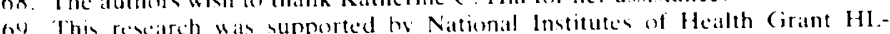
167.48

70. Regueses for reprints should be addressed to: lata S. Nerurkar. Ph.D.. the (conter for Interdisciplinary Studies of Immunology at Cieorgetown. (icorgetewn University School of Medicine. 130 Gorman Bldg.. 3800) Rescruir Road N.W'. Washington. D.C. 20007 (LISA)

71. Received tor publication January 26. 1977

72. Accepted for publication April it. 1977

Printed in U.S.A. 